\title{
SYNERGISM OF PDL/PD1 AND IL33/ST2 AXIS IN TUMOR IMMUNOLOGY
}

Marina Jovanovic, Nevena Gajovic, Miodrag L. Lukic, Ana Popovic, Ivan Jovanovic

Center for Molecular Medicine and Stem Cell Research, Faculty of Medical Sciences, University of Kragujevac, Serbia

\section{SINERGISTIČKI EFEKAT PDL/PD1 I IL-33/ST2 SIGNALNIH PUTEVA U TUMORSKOJ IMUNOLOGIJI

\section{ABSTRACT}

When it comes to tumor immunology, understanding of molecular pathways is rather important. During oncogenesis, many molecules should be taken in consideration altogether in context of a single malignancy. It is of a great significance to determine whether these molecules act synergistically or contrary, whether to understand a malignant disease more thoroughly, or even more important, to reveal new approaches of therapy. In this review, we discuss whether and how IL-33/ST2 and $P D-1 / P D L$ axis involve in antitumor immunity.

Keywords: $I L-33, P D-1$, tumor, antitumor immunity

\section{SAŽETAK}

U tumorskoj imunologiji, molekularni signalni putevi mogu biti veoma važni. U toku nastajanja tumora, treba razmatrati veliki broj molekula u okviru jedne maligne bolesti. Od velike je važnosti utvrditi da li ti molekuli deluju sinergistički ili ne, bilo da se radi o boljem poznavanju biologije odredenog tumora, ili, još važnije, otkrivanju novih terapisjkih pristupa. U ovom preglednom članku, mi razmatramo da li i kako IL-33/ST2 i PD-1/PDL signalni putevi utiču na antitumorsku imunost.

Ključne reči: $I L-33, P D-1$, tumor, antitumorska imunost

\section{INTRODUCTION}

In terms of tumor immunology (oncology), there are myriad of molecules that participate in process of malignant transformation of a cell. Many of these intertwine to breed or to restrain oncogenesis. In order to find better and new treatment of a malignant disease, it is important to understand how cancers grow, metastasize and triumph over immune response. During this process, many molecules should be taken in consideration altogether in context of a single malignancy. It is of a great significance to determine whether these molecules act synergistically or contrary - especially when it comes to new approaches of therapy. In this review, we will try to summarize current data on two molecules that are well known in tumor immunology - IL-33 and PD-1.

\section{INTERLEUKIN-33}

Interleukin-33 (IL-33) is a member of the IL-1 family of cytokines, which includes many cytokines, such as IL-1 $\alpha$ and $\beta$, IL-18, IL-36 $\alpha, \beta, \gamma$, IL-37, IL-38. They share similar signaling molecules, like MyD88 adaptor, IL-1 receptor (IL-1R1) and IL-1 receptor accessory protein (IL-1RAcP) $(1,2)$. However, in contrast to other IL-1 family cytokines, IL-33 may function as a cytokine, as alarmin, or as a nuclear factor which modulates expression of many genes, especially NF-kB $(3,4)$. Expression of IL-33 has been found in a variety of tissues, including stomach, lung and prostate; however, in contrast to other family members that are expressed predominantly in immune cells, IL-33 can be expressed in endothelial cells, epithelial cells and fibroblasts $(5,6)$. IL-33 plays an important role in tissue repair, allergy, 
autoimmune disease, infectious disease, and cancer. These roles are carried out through its receptor, Suppressor of Tumorigenicity 2 (ST2), which is broadly expressed on immune cells, such as regulatory $\mathrm{T}$ cells (Treg), group 2 innate lymphoid cells (ILC2s), myeloid cells, cytotoxic NK cells, Th2 cells, Th1 cells, and CD8 ${ }^{+} \mathrm{T}$ cells (7).

\section{ROLE OF INTERLEUKIN 33 IN BIOLOGY OF TUMOR AND ANTITUMOR IMMUNITY}

Having in mind these multiple functions and its versatility of expression, the role of IL-33 has been investigated in many areas of immune response, particularly in tumor immunology. IL-33 can either stimulate or inhibit antitumor immune response, depending on the type of tumor, or tumor microenviroment (summarized in table 1).

It has been shown that exogenous IL-33 enhanced the infiltration of $\mathrm{CD}^{+}, \mathrm{CD} 8^{+} \mathrm{T}$ cells and tumor antigen- specific $\mathrm{CD}^{+} \mathrm{T}$ cells in established melanoma. Moreover, there is significantly increased IFN- $\gamma$ production and KLRG1 expression in tumor-infiltrating $\mathrm{CD}^{+} \mathrm{T}$ cells after applying exogenous IL-33 (8-10). Main outcome of these changes is enhancement of antitumor immune response. Also, in a study conducted by Yang et al, it is shown that IL-33 expression is significantly lower in tumor tissue than adjacent healthy pulmonary tissue. The expression was verified by immunohistochemistry and PCR. IL-33 and its receptor, ST2, are significantly down-regulated in pulmonary adenocarcinoma compared to adjacent healthy lung tissues. In addition, the level of IL-33 protein in adenocarcinoma inversely correlates with tumor grade and size. Moreover, higher expression of IL-33 mRNA in tumor tissue correlates with longer overall survival of patients suffering from adenocarcinoma (11). In pulmonary adenocarcinoma, IL -33 restores dendritic cells activation and maturation by interacting with ST2 receptor on dendritic cells, induces co-stimulatory molecule expression and in that way triggers the type I antitumor immune responses by having a direct effect on $\mathrm{CD}^{+} \mathrm{T}$ cells and NK cells (12).

Other studies suggest protumorigenic role of IL-33. In a mouse model of 4T1 mammary carcinoma, in ST2 $2^{-1-}$ mice decreased metastasis was observed. In our study, we have shown that in $\mathrm{ST}^{-/-}$mice, tumor appearance is delayed and the growth of primary tumor is slower. Moreover, ST2 deletion significantly decreased number of pulmonary metastasis in ST2 ${ }^{-/}$mice compared to WT mice. Molecular mechanisms underlying these differences are attributable to higher numbers and efficacy of effector cells. Firstly, ST2 deletion increased total numbers of $\mathrm{CD}^{+}$and $\mathrm{CD}^{+} \mathrm{T}$ cells. Secondly, cytotoxicity of both NK and $\mathrm{CD}^{+} \mathrm{T}$ cells is constitutively higher in ST-/- compared to WT mice (13).

In a mouse model of metastatic colorectal carcinoma, similar results were obtained. When IL-33 was given along with MC38 tumor cell line, higher incidence of liver metastasis was detected, compared to MC38 tumors only. However, there were no differences concerning matrix metalloproteinases (MMPs) or lysil-oxidases (LOX), enzymes that are important for tumor metastasis. As no morphological differences were observed, authors concluded that increased metastatic potential is not attributed to cancers cells only and its changed properties and it is rather a result of other processes like enhanced angiogenesis. Also, there are increased numbers of $\mathrm{CD} 11 \mathrm{~b}^{+} \mathrm{F} 4 / 80^{+}$macrophages and $\mathrm{CD} 11 \mathrm{~b}^{+} \mathrm{Gr} 1^{+} \mathrm{MDSCs}(14)$. In presence of signaling of IL33/ST2 axis, number of immunosuppressive cells in tumor stroma increases $(15,16)$.

IL-33 promotes tumor growth through recruiting immunosuppressive cells, such as myeloid-derived suppressor cells (MDSC) or Tregs. Also, IL-33 can stimulate type 2 of innate lymphoid cells, mast cells or alternatively activated macrophages (M2), favoring in that way type 2 immune response, which is inefficient in tumor elimination $(17,18)$. Some authors speculate that it is possible that the nuclear localization of full-length IL-33 also have important role in tumor genesis (19).

IL-33, as mentioned, can have both, antitumorigenic or protumorigenic role. Dual and opponent role in genesis of malignancies of a single molecule is yet to be clarified. It has been speculated that downregulation of IL-33 in epithelial cells can lead to development of a malignancy. In the same way, upregulation of IL-33 in the tumor stroma and serum can lead to inefficient tumor immune response. IL-33 expression on tumor cell promotes type I antitumor immune response through $\mathrm{CD}^{+} \mathrm{T}$ cells and NK cells, and thus makes tumor more immunogenic. On contrary, IL-

Table 1. IL-33/ST2 axis in antitumor immunity

\begin{tabular}{|c|c|c|c|}
\hline & Cells & Markers & Study \\
\hline \multirow{3}{*}{$\begin{array}{c}\text { Effects of blocking IL33/ST2 } \\
\text { signaling }\end{array}$} & $\uparrow \mathrm{CD}^{+} \mathrm{T}$ cell & $\uparrow \uparrow I F N-\gamma$ & Jovanovic et al (2011) \\
\hline & $\uparrow$ NK cells & $\begin{array}{c}\uparrow \uparrow \mathrm{IFN}_{-} \gamma \\
\uparrow \uparrow \mathrm{CD} 11 \mathrm{~b} \\
\uparrow \uparrow \mathrm{CD} 27\end{array}$ & Jovanovic et al (2011) \\
\hline & $\begin{array}{c}\text { Tumor cells } \\
\text { (mammary carcinoma) }\end{array}$ & $\downarrow \downarrow$ VEGF & Milosavljevic et al (2015) \\
\hline \multirow{3}{*}{ Effects of IL33/ST2 signaling } & MDSCs & $\begin{array}{l}\downarrow \text { Accumulation in tumor micro- } \\
\text { enviroment }\end{array}$ & Xiao et al (2015) \\
\hline & ILC2 & $\begin{array}{c}\uparrow \mathrm{IL}-13 \\
\uparrow \mathrm{Th} 2 \text { response }\end{array}$ & Li et al (2014) \\
\hline & Tregs & $\begin{array}{l}\uparrow \mathrm{IL}-10 \\
\uparrow \mathrm{TGF} \beta\end{array}$ & Siede et al (2016) \\
\hline
\end{tabular}


33 expression in tumor stroma facilitates immune suppression via Tregs and MDSCs, so the tumor is less immunogenic and more prone to faster growth and higher incidence of metastasis (20).

\section{PROGRAMMED DEATH 1 MOLECULE}

PD-1 (CD279) molecule was first discovered in 1992, when it was thought to play important role in the process of programmed death (hence the name - programmed death 1, PD 1). It was thought that all immune cells that enter apoptosis synthesize de novo this protein, express it on the outer membrane and undergo apoptosis (21). Since then, blocking of PD-1 was studied regarding all aspects of immune response, maybe most thoroughly in tumor immunology.

PD-1 molecule, along with CTLA-4, LAG-3, TIGIT, TIM-3, inhibits activation of immune cells. These molecules are referred to as checkpoint inhibitors (22). Many cells express PD-1, such as CD4 ${ }^{+} \mathrm{T}$ cells, $\mathrm{CD}^{+} \mathrm{T}$ cells, $\mathrm{B}$ cells, natural killer $\mathrm{T}$ cells, activated monocytes, dendritic cells, macrophages. In physiological circumstances, it works as molecule that limits immune response and therefore prevents excessive tissue damage and protects from autoimmunity (23-25). Also, PD-1 is highly expressed on $\mathrm{T}$ cells that are exposed to antigens for a long time, which makes it a marker of exhausted T cells $(26,27)$. PD-1 molecule structurally belongs to immunoglobulin family. It contains one extracellular immunoglobulin domain and two intracellular tyrosine-based signaling motifs- ITSM (Immunoreceptor tyrosine-based Switch Motif) and ITIM (Immunoreceptor tyrosine-based Inhibitory Motif). Upon activation, these motifs dephosphorylate and inhibit many signaling molecules and adaptor proteins that are crucial for activation of $\mathrm{T}$ cells (28).

Expression of PD-1 is mainly induced by signals from antigenic receptors of $\mathrm{T}$ cells (TCR) or B cells (BCR) during immune cell activation, but many cytokines also induce PD-1 activation, especially IL-2, IL-7, IL-15 and interferons $(29,30)$.

There are two known ligands for PD1: PD-L1 and PDL2. Both of them contain immunoglobulin-like extracellular domains, similarly like B7 family of costimulators. Although they have same function, PD-L1 and PD-L2 differ to some extent. PD-L1 inhibits T-cell function in peripheral tissues, whereas PD-L2 suppresses immune T-cell activation in lymphoid organs. PD-L2 has a higher affinity for PD-1. Also, unlike PD-L2, PD-L1 can bind to a costimulator molecule, B7-1 (31). PD-L1 is constitutively expressed on many cell types - dendritic cells, macrophages, myeloid cells, T cells, B cells, and few non - hematopoietic cells (vascular endothelial cells, fibroblasts, epithelial cells, neurons and even on some cells at sites of immune privilege). PD-L2 is expressed on dendritic cells, macrophages, peritoneal B1 B, memory B cells $(32,33)$. In spite of these differs in sites of expression, both can be induced by cyto- kines, such as IL-2, IL-7, IL-15, TNF- $\alpha$ and interferons, especially IFN- $\gamma(34,35,36)$.

\section{ROLE OF PD1/PDL AXIS IN ANTITUMOR IMMUNITY}

PD1/PDL axis suppresses immune responses, by blocking mainly $\mathrm{T}$ cells in effector phase. In that way, this axis inhibits $\mathrm{T}$ cell proliferation and promotes anergy and apoptosis of activated T cells (37). When PD1/PDL axis is activated, it stops the function of $\mathrm{CD}^{+}$and NK cells that can be crucial for immune responses to tumors. It also polarizes $\mathrm{CD}^{+}$lymphocytes to forming regulatory $\mathrm{T}$ cells, and therefore creates immunosuppressive environment suitable for arising all kinds of diseases, especially malignant. Upon activation, this axis increases activation of a indoleamine-2,3-dioxygenase (IDO), enzyme that degrades tryptophan, amino acid essential for normal function of immune cells. When deprived of tryptophan, $\mathrm{T}$ cells tend to become regulatory cells or remain inactivated (38). Even if PD-1 or PDL expression is high on non - hematopoietic cells, it can create immunosuppressive conditions, whether by forming Tregs or inactivating effector cells. It is worth mentioning that Tregs constitutively express higher levels of PD-1; hence, once created, they tend to maintain immunosuppressive conditions. Data from a study by Chen et al suggest that $\mathrm{CD}^{+}{ }^{+} \mathrm{T}$ cells without PD-1 molecule have significantly lower predisposition to become regulatory cells, thus showing that formation of immunosuppressive cells specific for tumor antigens is one of the main mechanisms of PD1/PDL axis (39). Tumor cells can be induced to express ligands for PD1, depending on tumor microenvironment. If anti tumor immune response is strong and there are a lot of cytokines involved, such as IFN- $\gamma$, TNF- $\alpha$, PDL expression increases. In that way, tumors acquire immune resistance $(40,41)$.

\section{ANTI PD-1/PD-L THERAPY}

Having in mind all of the above mentioned consequences of activation PD1/PDL axis, it is no wonder that blocking of PD-1 or PDL is currently being considered as a new, promising treatment for autoimmune diseases and malignancies (42). Up to this day, there are five FDA approved monoclonal antibodies that block PD1 or PDL - nivolumab, pembrolizumab, atezolizumab, duvalumab, avelumab. These are used for treatment of some malignancies (renal cell carcinoma, urothelial carcinoma, Hodgkin lymphoma, hepatocellular carcinoma, head and neck carcinoma, mismatch-repair colorectal carcinoma) since 2013 and are currently being investigated in many more types of tumors (43).

Anti PD-1 or anti PD-L therapy improves anti tumor immune response by enhancing life span and performance of effector CD $8^{+}$cells, NK cells, NKT cells and even den- 


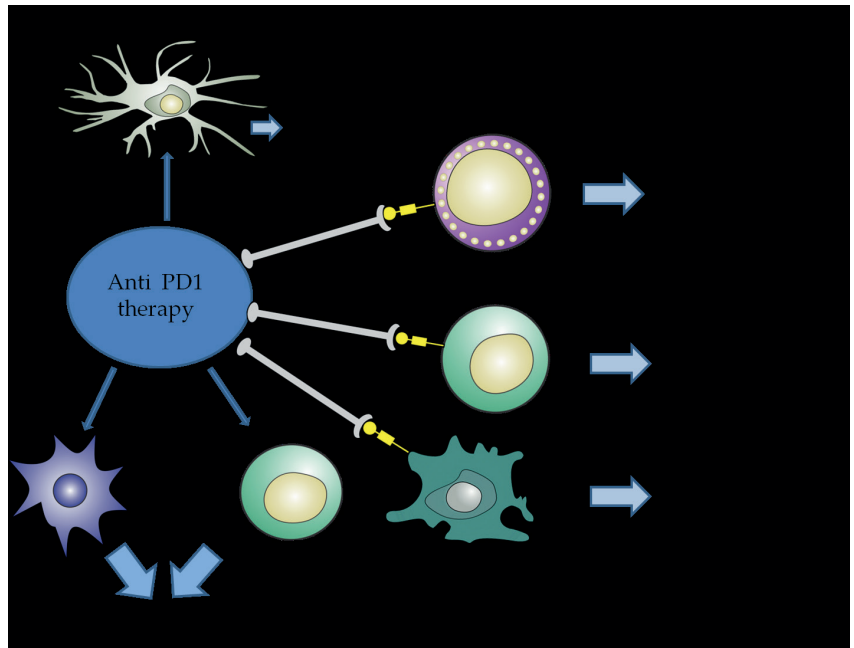

Figure 1. Effect of anti-PD1 therapy. By blocking PDL/PD1 axis, effector cells (cytotoxic T cells, helper T cells, macrophages, etc) become more efficient, have longer half life. Also, immunosuppressive cells are less generated. Overall result of these effects is enhanced antitumor response.

dritic cells (Figure 1). Result of these actions is instantly restored adequate tumor immune response and its overall augmentation (44). One of the good sides of anti PDL/PD1 therapy is certainly its possibility to be combined with other therapeutic drugs, especially other checkpoint inhibitors, or even radiotherapy and surgery. These modalities of treatment of a malignancy, when combined with anti PDL/ PD1 therapy show beneficial outcomes. (45-48).

\section{COMBINED BLOCKADE OF IL33/ST2 AND PDL/PD1}

Emphasis in treating malignancies is nowadays, without doubt, immunotherapy. To define new or redefine old protocols for treating a malignant disease, it would be convenient to discover potential molecular pathways that could act simultaneously in order to advance anti tumor immune response or suppress tumor invasiveness. Data on combining blockade of IL33/ST2 and PDL/PD1 are very modest. Until now, there is only one study that examines combined effect of these signaling pathways. In a mouse model of acute myeloid leukemia, an immunogenic hematological malignancy, application of exogenous IL-33 itself delayed the onset of leukemia. IL-33 treatment increases production of IFN- $\gamma$ and IFN- $\gamma$ producing $C D 8^{+} \mathrm{T}$ cells resulting with more efficient immune response against leukemia. Also, in these conditions, there are greater numbers of active antigen-specific CD8 ${ }^{+} \mathrm{T}$ cells. Unfortunately, with higher production of IFN- $\gamma$, it is possible and expected to have higher expression of PDL1 or even PD1. So, even if IL-33 overcomes peripheral tolerance to malignancy, it also can form ideal circumstances for blocking immune response through PDL/PD1 axis. When a checkpoint inhibitor is added to this therapy, peripheral tolerance is more thoroughly deprived. As expected, survival of mice that received combined therapy was significantly higher (49).
But what about non - immunogenic tumors? As mentioned before, IL-33 has diverce roles in development of these tumors. Some authors agree that every tumor can be immunogenic, i.e. there is always immune response to tumors; but, in non-immunogenic tumors it is rather impaired (50). Overcoming tolerance to tumors by blocking PDL/PD1 axis on the other hand and minimizing immunosuppressive circumstances via blocking IL33/ST2 axis could potentially reveal new, individualized and smarter approach to non - immunogenic malignant diseases.

\section{ACKNOWLEDGEMENTS}

This work was supported by grants from the Serbian Ministry of Science and Technological Development (175069, 175071 and175103), Serbia and from the Faculty of medical sciences Kragujevac (project JP 15/16), Serbia. The authors thank Milan Milojevic for excellent technical assistance.

\section{CONFLICT OF INTEREST}

The authors declare no financial or commercial conflict of interest.

\section{REFERENCES:}

1. Garlanda C, Dinarello CA, Mantovani A. The interleukin - 1 family: back to the future. Immunity. 2013;39(6):1003-1018.

2. Günther S et al. IL-1 Family Cytokines Use Distinct Molecular Mechanisms to Signal through Their Shared Co-receptor. Immunity. 2017 19;47(3):510-523

3. Wasmer M-H, Krebs P. The Role of IL-33-Dependent Inflammation in the Tumor Microenvironment. Frontiers in Immunology. 2016;7:682.

4. Ali S, Mohs A, Thomas M, Klare J, Ross R, Schmitz ML, Martin MU. The dual function cytokine IL-33 interacts with the transcription factor NF-kB to dampen NF- $\mathrm{BB}$-stimulated gene transcription. J Immunol. 2011;15;187(4):1609-16.

5. Gadina M, Jefferies CA. IL-33: a sheep in wolf's clothing? Sci STKE. 2007 Jun 12;2007:390.

6. Gao X et al.Tumoral expression of IL-33 inhibits tumor growth and modifies the tumor microenvironment through CD8+ T and NK cells. J Immunol. 2015 Jan 1;194(1):438-45

7. Lu B, Yang M, Wang Q. Interleukin-33 in tumorigenesis, tumor immune evasion, and cancer immunotherapy. J Mol Med; 2016;94(5):535-43

8. Dominguez D et al. Exogenous IL-33 Restores Dendritic Cell Activation and Maturation in Established Cancer. Immunol. 2017 1;198(3):1365-1375 
9. Amôr NG et al.ST2/IL-33 signaling promotes malignant development of experimental squamous cell carcinoma by decreasing NK cells cytotoxicity and modulating the intratumoral cell infiltrate. Oncotarget. 2018 Jul 20;9(56):30894-30904.

10. Lin SH et al. Inflammation elevated IL-33 originating from the lung mediates inflammation in acute lung injury. Clin Immunol; 2016; 30535-6.

11. Yang M, Feng Y, Yue C, Xu B, Chen L, Jiang J, Lu B, Zhu Y. Lower expression level of IL-33 is associated with poor prognosis of pulmonary adenocarcinoma. PLoS One. 2018 2;13(3).

12. Chen J et al.Interleukin-33 Contributes to the Induction of Th9 Cells and Antitumor Efficacy by Dectin-1-Activated Dendritic Cells. Front Immunol. 2018 31;9:1787.

13. Jovanovic I, Radosavljevic G, Mitrovic M, Juranic VL, McKenzie AN, Arsenijevic N, et al. (2011) ST2 deletion enhances innate and acquired immunity to murine mammary carcinoma. Eur J Immunol 41: 1902-1912.

14. Zhang $Y$ et al. IL-33 promotes growth and liver metastasis of colorectal cancer in mice by remodeling the tumor microenvironment and inducing angiogenesis. Mol Carcinog 56: 272-287.

15. Ishikawa $\mathrm{K}$ et al. Expression of interleukin-33 is correlated with poor prognosis of patients with squamous cell carcinoma of the tongue. Auris Nasus Larynx. 2014 Dec;41(6):552-7.

16. Chen SF et al. The paracrine effect of cancer-associated fibroblast-induced interleukin-33 regulates the invasiveness of head and neck squamous cell carcinoma. J Pathol. 2013 Oct;231(2):180-9.

17. Lu B, Yang M, Wang Q. Interleukin-33 in tumorigenesis, tumor immune evasion, and cancer immunotherapy. J Mol Med 94: 535-543.

18. Li J et al. Biliary repair and carcinogenesis are mediated by IL-33-dependent cholangiocyte proliferation. J Clin Invest. 2014; 124(7):3241-51.

19. Zhang JF et al. IL33 enhances glioma cell migration and invasion by upregulation of MMP2 and MMP9 via the ST2NF-кB pathway. Oncol Rep. 2017 Oct;38(4):2033-2042.

20. Xiao $P$ et al.Interleukin 33 in tumor microenvironment is crucial for the accumulation and function of myeloid-derived suppressor cells.Oncoimmunology. 2015. 24;5(1)

21. Ishida Y, Agata Y, Shibahara K, Honjo T. Induced expression of PD-1, a novel member of the immunoglobulin gene superfamily, upon programmed cell death. EMBOJ. 1992 (11):3887-95

22. Park YJ, Kuen DS, Chung Y. Future prospects of immune checkpoint blockade in cancer: from response prediction to overcoming resistance.Exp Mol Med. 2018 22;50(8):109.

23. Francisco LM, Sage PT, Sharpe AH. The PD-1 pathway in tolerance and autoimmunity. Immunol Rev. 2010; 236: $219-242$.

24. Ortler S et al. B7-H1 restricts neuroantigen-specific T cell responses and confines inflammatory CNS dam- age: implications for the lesion pathogenesis of multiple sclerosis. Eur J Immunol. 2008;38(6):1734-44

25. Sharpe AH, Pauken KE. The diverse functions of the PD1 inhibitory pathway. Nat Rev Immunol. 2018;18(3):153-167

26. Zou W, Chen L. Inhibitory B7-family molecules in the tumour microenvironment. Nat Rev Immunol. 2008; 8: 467- 477.

27. Gupta PK et al. CD39 Expression Identifies Terminally Exhausted CD8+ T Cells. PLoS Pathog. 2015;11(10):e1005177.

28. Starr R et al. A family of cytokine-inducible inhibitors of signalling. Nature. 1997; 387: 917-921.

29. Massari F et al. PD-1 blockade therapy in renal cell carcinoma: current studies and future promises. Cancer Treat Rev. 2015; 41: 114-121.

30. Ahmad SM et al. The inhibitory checkpoint, PD-L2, is a target for effector T cells: Novel possibilities for immune therapy. Oncoimmunology. 2017;7(2): e1390641.

31. Francisco LM, Sage PT, Sharpe AH. The PD-1 pathway in tolerance and autoimmunity. Immunol Rev. 2010;236:219-42.

32. Reynolds J et al. Stimulation of the PD-1/PDL-1 T-cell co-inhibitory pathway is effective in treatment of experimental autoimmune glomerulonephritis. Nephrol Dial Transplant. 2012 Apr;27(4):1343-50.

33. Keir ME, Butte MJ, Freeman GJ, Sharpe AH. PD-1 and its ligands in tolerance and immunity. Annu Rev Immunol. 2008; 26:677-704.

34. White MPJ, Webster G, Leonard F, La Flamme AC. Innate IFN- $\gamma$ ameliorates experimental autoimmune encephalomyelitis and promotes myeloid expansion and PDL-1 expression. Sci Rep. 2018 Jan 10;8(1):259.

35. Rowe JH, Ertelt JM, Way SS. Innate IFN- $\gamma$ is essential for programmed death ligand-1-mediated T cell stimulation following Listeria monocytogenes infection. J Immunol. 2012;189(2):876-84.

36. Riley JL. PD-1 signaling in primary $\mathrm{T}$ cells. Immunol Rev. 2009; 229: 114-125.

37. Okazaki T, Maeda A, Nishimura H, Kurosaki T, Honjo T. PD-1 immunoreceptor inhibits B cell receptor-mediated signaling by recruiting src homology 2-domaincontaining tyrosine phosphatase 2 to phosphotyrosine. Proc Natl Acad Sci U S A. 2001; 98: 13866-13871.

38. Schlößer HA, Theurich S, Shimabukuro-Vornhagen A, Holtick U, Stippel DL, von Bergwelt-Baildon M. Overcoming tumor-mediated immunosuppression. Immunotherapy., 2014; 6: 973-988

39. Chen $X$ et al. PD-1 regulates extrathymic regulatory T-cell differentiation. Eur J Immunol. 2014; 44: 26032616.

40. Meng Y, Liang $\mathrm{H}, \mathrm{Hu}$ J, Liu S, Hao X, Wong MSK, Li $\mathrm{X}, \mathrm{Hu}$ L. PD-L1 Expression Correlates With Tumor Infiltrating Lymphocytes And Response To Neoadjuvant Chemotherapy In Cervical Cancer. J Cancer. 2018;9(16):2938-2945. 
41. Kim JM, Chen DS. Immune escape to PD-L1/PD-1 blockade: seven steps to success (or failure). Ann Oncol. 2016;27(8):1492-504.

42. Taube JM et al. Colocalization o inflammatory response with B7-h1 expression in human melanocytic lesions supports an adaptive resistance mechanism of immune escape. Sci Transl Med. 2012 28;4(127):127

43. Cheng B, Yuan WE, Su J, Liu Y, Chen J. Recent advances in small molecule based cancer immunotherapy. Eur J Med Chem. 2018;157:582-598.

44. Ostrand-Rosenberg S, Horn LA, Haile ST. The programmed death-1 immune-suppressive pathway: barrier to antitumor immunity. J Immunol. 2014 Oct 15;193(8):3835-41.

45. Larkin J et al. Combined Nivolumab and Ipilimumab or Monotherapy in Untreated Melanoma. N Engl J Med. 2015;373(13): 1270-1.

46. Roger A et al. Efficacy of combined hypo-fractionated radiotherapy and anti-PD-1 monotherapy in difficult- to-treat advanced melanoma patients. Oncoimmunology. 2018;7(7): e1442166.

47. Zeng J, See AP, Phallen J, Jackson CM, Belcaid Z, Ruzevick J, Durham N, Meyer C, Harris TJ, Albesiano E, Pradilla G, Ford E, Wong J, Hammers HJ, Mathios D, Tyler B, Brem H, Tran PT, Pardoll D, Drake CG, Lim M. Anti-PD-1 blockade and stereotactic radiation produce long-term survival in mice with intracranial gliomas. Int J Radiat Oncol Biol Phys. 2013;86(2):343-9.

48. Choi N, Shin DY, Kim HJ, Moon UY, Baek KH, Jeong HS. Postoperative anti-PD-1 antibody treatment to reduce recurrence in a cancer ablation surgical wound. J Surg Res. 2018;221:95-103.

49. Qin L et al. Exogenous IL-33 overcomes T cell tolerance in murine acute myeloid leukemia. Oncotarget. 2016;7(38):61069-61080.

50. Blankenstein T, Coulie PG, Gilboa E, Jaffee EM. The determinants of tumour immunogenicity. Nat Rev Cancer. 2012 1;12(4):307-13. 